\title{
Obituary for a Cartographer - Indra Narayan Manandhar, 1941 - 2011
}

Indra Narayan Manandhar was born on September 7, 1941 in Jhochhen Layakusa, Kathmandu, Nepal. He died on June 26, 2011 in Kathmandu at the age of $70 . \mathrm{He}$ did Master's Degree in Geography from Tribhuvan University, Nepal in 1968 and M.Sc. in applied geomorphological surveys from International Institute for Aerospace Survey \& Earth Science, The Netherlands in 1987. He joined Central Department of Geography, Tribhuvan University in 1973 as an Assistant Lecturer and promoted to Associate Professor in 1988. He had served the Central Department of Geography as a

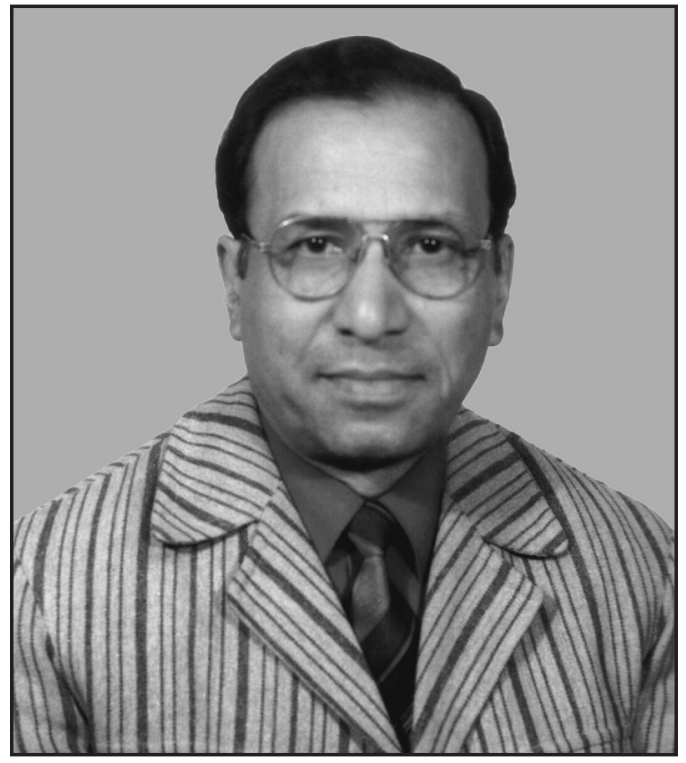
Head of the Department from 2003-2004.

He had also served the Department of Geography, University of Bergen, Norway as the Visiting Professor (April-June, 1998).

\section{An academic}

Late Manandhar was one of the energetic and delightful geographers and professors at the Central Department of Geography, TU, Kirtipur, Kathmandu, Nepal with over 31 years of teaching and research experience. He was retired in 2004. He had more than 10 publications including articles in journals, books and newspaper articles. He had substantial contribution to prepare Mechi Dekhi Mahakali (District Gazetteer book of Nepal in four volume published by the Department of Information and Publication, Ministry of Communication, Government of Nepal in 1973). He had attended and contributed several national and international level seminars and conferences. He had 
served as Editor for the Himalayan Review, the Journal of Nepal Geographical Society (1968-1974). He had completed more than 12 research projects.

\section{A skillful cartographer}

As a cartographer, he was involved in preparing and publishing maps such as Kathmandu City (1975), National Fertility (1981), Geomorphological map of the Hoya Hoya De Malaga, Spain (1984), and Election Profile (2000). He had organized and co-ordinated training programs on Desktop Cartography (1995-1996) in the Department.

\section{An adventurous excursionist}

Late Manandhar was an adventurous excursionist. He had organized excursion tours for the students of the Department almost every year and travelled extensively different parts of Nepal.

The Central Department of Geography has lost a prominent geographer who was highly committed for the development of geography education and research. The noteworthy memories of sincerity, frankness and friendliness he has left for us are unforgettable to follow. The department family members (CDG) extend their deepest condolence to his family. 